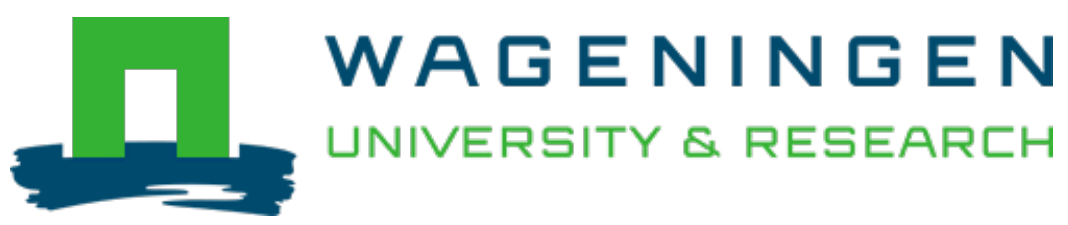

\title{
Integrated Pest Management Methods and Considerations Concerning Implementation in Greenhouses
}

\author{
Integrated Pest and Disease Management in Greenhouse Crops \\ Lenteren, Joop C.; Nicot, Philippe C. \\ https://doi.org/10.1007/978-3-030-22304-5 6
}

This article is made publicly available in the institutional repository of Wageningen University and Research, under the terms of article $25 \mathrm{fa}$ of the Dutch Copyright Act, also known as the Amendment Taverne. This has been done with explicit consent by the author.

Article 25 fa states that the author of a short scientific work funded either wholly or partially by Dutch public funds is entitled to make that work publicly available for no consideration following a reasonable period of time after the work was first published, provided that clear reference is made to the source of the first publication of the work.

This publication is distributed under The Association of Universities in the Netherlands (VSNU) 'Article $25 \mathrm{fa}$ implementation' project. In this project research outputs of researchers employed by Dutch Universities that comply with the legal requirements of Article $25 \mathrm{fa}$ of the Dutch Copyright Act are distributed online and free of cost or other barriers in institutional repositories. Research outputs are distributed six months after their first online publication in the original published version and with proper attribution to the source of the original publication.

You are permitted to download and use the publication for personal purposes. All rights remain with the author(s) and / or copyright owner(s) of this work. Any use of the publication or parts of it other than authorised under article $25 \mathrm{fa}$ of the Dutch Copyright act is prohibited. Wageningen University \& Research and the author(s) of this publication shall not be held responsible or liable for any damages resulting from your (re)use of this publication.

For questions regarding the public availability of this article please contact openscience.library@wur.nl 


\title{
Chapter 6 \\ Integrated Pest Management Methods and Considerations Concerning Implementation in Greenhouses
}

\author{
Joop C. van Lenteren and Philippe C. Nicot
}

\begin{abstract}
We consider IPM as a combination of durable, environmentally, toxicologically and economically justifiable farming practices which prevent pest damage primarily through the use of natural factors limiting pest population growth and disease development, and which resort only if needed to other, preferably nonchemical, measures. IPM is not simply a combination of various control methods. We give an overview of IPM measures used in greenhouses and refer to specific chapters in this book for examples. In IPM, each practical situation dictates a number of special aspects for consideration, and IPM methods need continuous adaptation, making IPM knowledge intensive and interactive. Successful IPM programmes for greenhouse crops have a number of characteristics in common: (a) their use was promoted only after a complete IPM programme had been developed, (b) intensive support by the extension service was essential during initial implementation, (c) the costs of crop protection with IPM should not be higher than those of a chemical control programme, and (d) non-chemical management methods, such as biocontrol agents and resistant plant material, should be as easily available, as reliable, and as constant in quality, as chemical agents. IPM research and implementation in greenhouses during the past 50 years has taught us the lesson that the development of an IPM programme needs to be discussed in a very early stage with all stakeholders, including growers, pest management specialists, extension services and researchers. Such a meeting often results in a pragmatic design of a draft, very pragmatic IPM programme, which is continuously adapted during later meetings, based on growers' experience and new research results.
\end{abstract}

\footnotetext{
J. C. van Lenteren $(\bowtie)$

Laboratory of Entomology, Wageningen University, Wageningen, The Netherlands e-mail: Joop.vanLenteren@wur.nl

P. C. Nicot

Plant Pathology Unit, INRAE, Montfavet, France

e-mail: philippe.nicot@inra.fr
} 
Keywords Pest prevention · Pest reduction - Cultural control · Curative control · Host-plant resistance $\cdot$ Natural biocontrol $\cdot$ Classical biocontrol $\cdot$ Conservation biocontrol $\cdot$ Augmentative biocontrol $\cdot$ Semiochemical control

\subsection{Introduction}

Integrated pest ${ }^{1}$ management (IPM) has been defined in many ways, from very pragmatic (the use of a combination of all kinds of management techniques to reduce pest problems) to ecologically and philosophically based ones (the use of ecosystem services and non-chemical management techniques and only in very exceptional cases selective chemical control as a last resort) (Radcliffe et al. 2009). The original meaning of IPM, also expressed in the definition given below, has often been corrupted, and is sometimes even used to denote Integrated Pesticide Management, Intelligent Pesticide Marketing or pesticide-dominated control programmes with the addition of a single non-synthetic pesticide. In this chapter, we will use a definition (adapted from Gruys, P., in van Lenteren 1993) that reflects our concern for biodiversity and the environment, but takes the economics of crop production into account: IPM is a combination of durable, environmentally, toxicologically, and economically justifiable farming practices which prevent pest damage primarily through the use of natural factors limiting pest population growth and disease development, and which resort only if needed to other, preferably non-chemical, measures.

From the time agriculture developed some 10,000 years ago until 1945, farming was based on a systems approach and crop protection programmes relied first of all on prevention methods of pests and diseases based on natural factors, because chemical control measures were not abundantly available. Thus, for ages crop protection was based on IPM and included, among others, periods of fallow, planning of crop combinations, crop rotation, tillage, use of resistant or tolerant crop cultivars, choice of the right planting and harvesting periods, biological, mechanical and physical control, etc. Due to developments in plant genetics, and the production of synthetic fertilizers and pesticides, agricultural research changed from a systems approach into an extremely reductionist science where pests are controlled by preventive calendar sprays and curative treatments with chemical pesticides. However, during the past decades it has become clear that reliance on pesticides may give rise to all kinds of problems, such as the development of resistance to pesticides by pests resulting in a pesticide treadmill with ever increasing treatment frequencies or volumes, the enhancement of secondary pests because of a decimation of natural enemies by pesticide treatments, the pollution of water, soil and air, the reduction of biodiversity and the interference with ecosystem services such as water and soil cleaning, pollination and crop protection, the production of food with pesticide residues and a variety of direct and indirect negative impacts on human health (Bourguet

\footnotetext{
${ }^{1}$ The word pest is used in this chapter as defined by FAO/IIPC (1997), and includes weeds and animal pests as well as causal agents of diseases.
} 
and Guillemaud 2016; Erisman et al. 2016; Pimentel and Burgess 2014; Tillman et al. 2012). Nowadays, consumers and in a number of cases also governments, are stressing the need for a drastic reduction in the use of chemical pesticides and plea for healthier food and a cleaner environment (Buurma et al. 2012; EC 2009). In this chapter we will illustrate that there are many non-chemical alternatives for pesticides even in the setting of crop production in greenhouses, and that a shift from pure chemical control to IPM is occurring worldwide (Pérez-Hedo et al. 2017).

Before we present these alternatives, we want to express that we are not advocating dogmatic, one-sided pest control approaches for greenhouse crops. Instead, we propose to combine the sustainability gain from all types of horticulture and pest prevention/control methods, including modern plant breeding. The fact that more creativity, knowledge and ecological insight are needed to be able to apply such pesticide-free/poor IPM crop management schemes should not be an excuse to keep using easier synthetic pesticide programme. Actually, IPM programmes for various greenhouse crops, including ornamentals, have shown to lead to higher yields and better quality of produce, and thus, a much better profit for the grower (see examples in Chaps.16 and 23).

\subsection{Methods Used in Integrated Pest and Disease Management in Greenhouses}

A wide variety of methods is available for IPM in the greenhouse (Table 6.1). They will be presented in relation to the timing of their implementation in the cropping season.

\subsubsection{Measures Taken Before the Cropping Season to Prevent Infection of the Crop}

The first line of defense is to try to prevent the introduction of new pests into a production area, but this is easier said than done. International organizations and national institutions have set up networks, regulations and inspection systems to prevent accidental introduction of new pests (see e.g. www.FAO.org, www.IIPC.int, www.efsa.europa.eu), but despite this, the number of new pests accidentally introduced is exponentially increasing and also forms a serious problem for greenhouse crops (Bacon et al. 2012; Seebens et al. 2017). In order to control invasive invertebrate pests, it was, until very recently, possible to collect potential biological control agents in the country of origin of the pest, and evaluate, mass produce and release them when an effective agent was found. But today, under the Convention on Biological Diversity (CBD 1993) countries have sovereign rights over their genetic resources, and agreements governing the access to these resources and the sharing of benefits arising from their use need to be established between involved parties 
Table 6.1 Methods to prevent or reduce pest populations in greenhouses

\begin{tabular}{|c|c|c|}
\hline IPM method & $\begin{array}{l}\text { Use in } \\
\text { Greenhouse IPM }\end{array}$ & $\begin{array}{l}\text { Chapter } \\
\text { treating this } \\
\text { issue }\end{array}$ \\
\hline \multicolumn{3}{|c|}{ Measures taken before the cropping season to prevent infection of the crop } \\
\hline $\begin{array}{l}\text { Prevent introduction of new pests (e.g. inspection and } \\
\text { quarantine) }\end{array}$ & + & 1 \\
\hline Apply cultural control (e.g. crop rotation) & $+1-$ & $10,17-22$ \\
\hline $\begin{array}{l}\text { Start with clean seed and plant material (e.g. thermal } \\
\text { disinfection) }\end{array}$ & + & $11,17-22$ \\
\hline $\begin{array}{l}\text { Start with pest free soil (steam sterilization, solarization } \\
\text { and biological control (e.g. Trichoderma)) }\end{array}$ & + & $12,17-22$ \\
\hline $\begin{array}{l}\text { Prevent introduction from neighboring crops (e.g. } \\
\text { netting) }\end{array}$ & + & $10,17-22$ \\
\hline Use plants which are fully resistant or tolerant to pests & + & $9,17-22$ \\
\hline \multicolumn{3}{|c|}{ Measures taken during the cropping season to reduce infection of the crop } \\
\hline Apply cultural control (e.g. trap crops) & $+1-$ & $5,10,17-22$ \\
\hline Use plants which are partly resistant or tolerant to pests & + & $9,17-22$ \\
\hline $\begin{array}{l}\text { Exploit natural classical, conservation and augmentative } \\
\text { biocontrol }\end{array}$ & $+/-$ & $14,17-22$ \\
\hline \multicolumn{3}{|l|}{ Apply one of the following curative control methods } \\
\hline $\begin{array}{l}\text { Mechanical control (mechanical destruction of pest } \\
\text { organisms, vacuum cleaners, hand/machine removal of } \\
\text { weeds) }\end{array}$ & + & 10 \\
\hline Physical control (heating, UV treatment; colour traps) & + & $10,17-22$ \\
\hline Control with attractants, repellants and antifeedants & $+1-$ & 14 \\
\hline $\begin{array}{l}\text { Control with pheromones (mass trapping, confusion } \\
\text { techniques) }\end{array}$ & + & $14,16-22$ \\
\hline $\begin{array}{l}\text { Control with other semiochemicals (repel pests, attract } \\
\text { beneficials) }\end{array}$ & $+1-$ & $14,16,18$ \\
\hline $\begin{array}{l}\text { Control with hormones (disrupt development, prevent } \\
\text { reproduction) }\end{array}$ & - & 14,19 \\
\hline Genetic control (sterile insect technique) & - & - \\
\hline Conservation and augmentative biological control & + & $13,14,17-22$ \\
\hline Selective chemical control & $+1-$ & 15 \\
\hline Non-selective broad spectrum chemical control & + & 15 \\
\hline $\begin{array}{l}\text { Guided or supervised pest management: control based on } \\
\text { sampling and spray thresholds }\end{array}$ & $+1-$ & 7 \\
\hline $\begin{array}{l}\text { IPM: control based on the integration of methods which } \\
\text { cause the least disruption of ecosystems }\end{array}$ & + & 7,16 \\
\hline
\end{tabular}

(i.e., Access and Benefit Sharing (ABS) (https://www.cbd.int/abs/); Cock et al. 2010)). Today, permission to sample biological control agents must first be granted by the country where one intends to collect new natural enemies, and practically it has become impossible to do so in many cases due to unclear and very time consuming bureaucratic procedures (Mason et al. 2018). The consequence is that one of the main sources to combat invasive species, i.e. by classical biological control, may have been cut off. 
Another method to prevent pest development is to start with clean seed and plant material, and this is used frequently in greenhouse IPM. For details about the many methods to obtain pest free seeds and plants, we refer to Chap. 11.

A start with a pest free growing substrate is also important and production on various soilless substrates is common, particularly in high-investment heated glasshouses. For greenhouses with plants grown on soil, the presence of soilborne pathogens is usually detrimental, with the exception of "suppressive soils" for which the resident microbiome is able to prevent disease development (Schlatter et al. 2017; Mazzola and Freilich 2017). When needed, a variety of non-chemical methods can be applied to reduce or eliminate soilborne pests. These methods include crop rotation, the use of trap plants, biofumigation, anaerobic soil disinfestation and stimulation of beneficial microbial communities through the cultivation of cover crops as green manure or the application of soil amendments or microbial biocontrol agents (Pannacci et al. 2017; Katan 2017; Shrestha et al. 2016; Mazzola and Freilich 2017). Soil solarization and biosolarization offer increasing possibilities against soilborne pests, with progress in mulching technology and synergistic combinations with various organic amendments or biocontrol agents (Katan 2017; Oka et al. 2007; Pane et al. 2012; Öz et al. 2017; Butler et al. 2014). Solarization and biosolarization are also increasingly noted for their possible role in decontaminating soil tainted with pesticide residues (Fenoll et al. 2017; Vela et al. 2017).

Mulching (with polyethylene film or organic matter) can also contribute to the protection of the crop by affecting the survival and development of soilborne pests (including weeds) through its many physical effects on the soil and the soil microbiota and by preventing direct contact between aerial plant organs and pests present at the soil surface.

To avoid the carry-over of pests from one crop to the next in the greenhouse (for example virus-vectoring insects, inoculum of plant pathogens as free propagules or embedded in plant debris or soil particles), it may be necessary to respect a plantfree period between successive crops and to clean thoroughly and disinfest the greenhouse structures. Disinfestation can be achieved by heat (steam or keeping the greenhouse closed during a hot weather period) or with the help of chemical disinfectants. Finally, growers can use completely closed glasshouse structures with advanced climate management, or glass or greenhouses where all openings at windows are covered with fine mesh netting to prevent entrance of pests.

\subsubsection{Measures Taken During the Cropping Season to Reduce Infection of the Crop}

Host-plant resistance is one of the important cornerstones of IPM and its role could become even more important for many greenhouse crops in the near future because of new genetic techniques (Chap. 9). Selection of plant resistance has been widely 
focused against diseases and it has remained less significant against arthropods, but we expect increasing interest for selection of arthropod resistance in crops. While full resistance is most commonly sought, partial plant resistance can also be quite useful in IPM. This is particularly true for pest control, as a slowdown in pest population development may greatly facilitate the beneficial effect of natural enemies. Both classic and modern plant breeding, including CRISPR-Cas and RNAi, will help us design robust IPM programmes. Changing plant characteristics by breeding can help pest and disease prevention in different ways: by making a plant less sensitive, repellent or even poisonous to a pest, but also by producing attractants for biological control agents after pest attack (Dicke 2016; Kappers et al. 2011), or by harbouring microbiomes that foster natural biocontrol. Plant architecture may also be selected for features which foster accessibility for natural enemies or render canopy structure and microclimate less conducive to disease or pest development (Grumet et al. 2013; Tivoli et al. 2013). Finally, susceptible varieties can be grafted on rootstock with resistance to various soilborne pests (Katan 2017; Louws et al. 2010; Gamliel and van Bruggen 2016), and resistance of the rootstock to airborne pathogens can sometimes also be of benefit to the grafted variety (Albert et al. 2017). Most varieties used as rootstock are also known to improve agronomic traits of the crop, including tolerance to abiotic stress (Schwarz et al. 2010). For several vegetable crops this practice is implemented on a large percentage of the acreage (Kyriacou et al. 2017; Louws et al. 2010) (Chaps. 17-19).

A wide array of cultural control methods may also be mobilized for IPM in the greenhouse (Chap. 10). These practices can render the physical environment of the crop less conducive to pest development, decrease the physiological receptiveness of a susceptible crop to its pests or have a direct suppressive effect on those pests. Avoiding periods of high humidity, dew formation on the plants and guttation is a key to limiting the incidence and the impact of most airborne fungal and bacterial diseases. Although cost may be an issue, this can be achieved through (often computer-controlled) climate management in heated glasshouses. Some level of climate management can also be achieved through ventilation in unheated greenhouses; in Mediterranean climates, moderate high temperatures in summer months is a key issue to extent cropping season. Microclimate within the canopy can be further modulated to be less favourable for the pests by adjusting row spacing, planting density, type and timing of irrigation, $\mathrm{N}$-fertilization and by adapting plant architecture, for example through leaf pruning (Decognet et al. 2010). Fertilization and water supply may also affect the physiological receptiveness of the plants to pathogens and the development of plant feeding pests (Datnoff et al. 2007; Han et al. 2014; Ximenez-Embun et al. 2017; Achuo et al. 2006; Nicot et al. 2012). However, the design of fertilization schemes for IPM purposes may be complicated by opposite effects for different pests and the need to take into account possible impact on yield (Nicot et al. 2012; Hoffland et al. 2000; Xu et al. 2013). Plant susceptibility may also be influenced by the application of a variety of compounds and microorganisms that stimulate its natural defence system. These typically include biopesticides (Chap. 13) and plant biostimulants, two types of products that are gaining increasing interest in horticultural production, for use as foliar or root treat- 
ments (Colla and Rouphael 2015; Le Mire et al. 2016; Pappas et al. 2017). Biostimulants comprise a great variety of compounds with numerous underlying biological processes and combined properties of fertilizers and plant protection products, a situation which complicates the definition of a clear regulatory framework for their registration (La Torre et al. 2016; Yakhin et al. 2017).

All types of biological control - natural, classical, conservation and augmentative - can be used to prevent population increase of pests to densities where they become damaging (Chaps. 13 and 14). Recent experience in Spain has shown, for example, that naturally occurring natural enemies in combination with growing nectar-and pollen-providing plants between greenhouses enhances biological control inside greenhouses. Another example is natural control of leafminers in the Netherlands; in the 1980s after invasions of different leafminer species into northern Europe we found that they are kept below damage levels as soon as the weather necessitates regular opening of windows for cooling and native parasitoids can enter the glasshouse. Also, preventative releases with natural enemies - a form of augmentative biological control - are increasingly made in young plantings of vegetables and ornamentals, even before the pest has been seen, in order to guarantee immediate reduction of pest populations when they enter the greenhouse (Calvo et al. 2012a). This is often done in combination with the use of banker plants so the natural enemies can establish on alternative food (Messelink et al. 2014). While virtually absent from the greenhouse 20 years ago, biological control agents and biopesticides are now increasingly available for the management of airborne plant pathogens (Nicot and Bardin 2012; van Lenteren 2000; van Lenteren et al. 2018). They include microorganisms with a variety of modes of action (Chap. 13), as well as plant extracts and other natural compounds. Commercial products are registered against the major pathogens of important vegetable crops, but there is still a large discrepancy between countries and some increasingly prevalent diseases such as downy mildew (late blight for tomato) are not well covered. Similarly, greenhouse crops include a large gamut of "minor" (mostly ornamental) crops, for which registration of biocontrol products is lagging behind.

Next to reduction of pests in an early phase of development, there are also many methods that can be used curatively. Mechanical control has been applied since the origin of agriculture in many different ways, starting with simple hand weeding, and hand removal of pest individuals or diseased plant parts. Mechanical removal of weeds is now also used and large "vacuum cleaners" specially designed for use in greenhouses can be used over young and/or relative small plants to remove arthropods. Also physical control has been used since long in the form of burning of pest infected material, or by placing sticky colour traps in the greenhouse (a combination of mechanical and physical control). Currently interesting developments take place, whereby disease causing organisms are filtered (mechanical control) and killed by UV treatment (physical control) of the irrigation water in drip irrigation systems where water is recirculated (Scarlett et al. 2016; Prenafeta-Boldu et al. 2017). Recently, aerial treatment with UV has been applied in greenhouses to destroy plant pathogens or reduce their infectivity (Suthaparan et al. 2017) and some potential has been shown of using hormetic doses of UV light to decrease plant susceptibility 
(Vargas-Hernandez et al. 2017). Many chemical attractants, repellents and antifeedants are on the market for the control of arthropod pests, but their use is limited in greenhouses. A special group of attractants are pheromones (chemical compound(s) produced by an organism that trigger(s) a response in an organism of the same species) and these are regularly used in greenhouses to monitor pest presence, to mass trap pests or as a confusion technique by putting an overdose of a synthetic sex pheromone in the greenhouse with the result that males can no longer find their female partner that emit the natural sex pheromone (see Chap. 14 for examples); this technique for monitoring and control is only feasible and useful in cases of Lepidoptera mating inside greenhouse but not for those pests that mostly mate outside the greenhouse and go into already mated. Also semiochemicals (chemical compounds playing a role in communication between organisms of the same or other species) form a special group of attractants and repellents: greenhouse multitrophic systems consisting of plants, pests and biological control agents are interacting, among others, with chemical communication. Some of the volatile chemical compounds produced on attack by a pest (a disease-causing organism or nematode attacking roots in the soil, or an insect attacking leaves of the plant) do attract natural enemies, and the same or other compounds repel pests or induce defence reactions in the plants (Dicke 2016). Knowledge about semiochemicals has quickly developed since the 1970s (e.g. Nordlund et al. 1981), but although there are now thousands of scientific publications and many claims have been made about their potentially positive contribution to pest management in IPM programmes, their practical use is still very limited in the greenhouse. We know of one published example showing, in a test with eight cucumber varieties equally infested with the spider mite Tetranychus urticae, that (1) these varieties emitted different compositions and quantities of volatiles, (2) the composition of the blends of emitted volatiles was more important than the volume, and (3) that amounts of 4 specific volatiles correlated positively with attraction of predatory mites. These results imply that foraging success of natural enemies can be enhanced by breeding for crop varieties that release specific volatiles after pest attack (Kappers et al. 2011). In some cases, pest control with synthetic growth hormones had been applied. These hormones disrupt development of the pest, prevent reproduction and are rather pest specific so can be integrated with other non-chemical management methods. Genetic control, for example by introducing large numbers of sterile males into the greenhouse so that females mate with these sterile males and do not reproduce, has been proposed for control of several pests, among others for whitefly, but is not popular in greenhouses. Augmentative biological control through the repeated release of beneficial organisms has been applied in greenhouses since the 1920s and is now a popular method for control of pests and diseases worldwide. Many biological control agents (parasitoids, predators, pathogens) are commercially available (Chaps. 13 and 14) and have shown to be as reliable as or better than chemical control (e.g. van Lenteren et al. 2018). Biological control has in several cases even saved the greenhouse sector, because chemical control of several key pests was no longer effective (e.g. Calvo et al. 2012b). Specific cases of biological control are mentioned in many of the following chapters, but a good recent example showing the large array of bio- 
control agents available for almost all key pests in tomato is presented by PérezHedo et al. (2017). Because of the high sensitivity of biological control agents for all groups of pesticides, including herbicides and fungicides, non-selective broad spectrum chemical control can not be used in IPM, unless their application is on selected spots and in low doses (Chap. 15). In IPM, selective chemical control can be used under strict conditions. First of all the grower should determine whether chemical control is necessary based on reliable sampling for pests in the crop. Next, a suitable selective chemical control method should be selected. An extensive overview of potential candidates to replace conventional synthetic pesticides can be found in Benuzzi and Ladurner (2017). Generally, when using biological control, the grower should try to delay spraying as long as possible to avoid killing beneficial organisms such as biocontrol agents and pollinators, and to prevent causation of secondary pests (pests that develop as the result of killing their natural enemies or antagonists and which normally do not cause problems when no or very selective pesticides are used; an example of a secondary pest is leafminers). If spraying is inescapable, it is recommended for arthropod control to spray only at pest foci, spray with lower than advised volumes of active ingredients, and use those selective pesticides that have limited negative effects on beneficial organisms. Spraying with lower than advised doses of fungicides for disease control is also increasingly done, but care should be taken not to increase concomitantly the frequency of treatments, as for certain pathogens this could foster the development of resistance (Jørgensen et al. 2017). Pesticide side-effect and selectivity data have been determined for many years by the working group "Pesticides and beneficial organisms"of IOBCWPRS (www.iobc.wprs.org) and information on side effects can now be accessed on the internet (e.g. Www.iobc-wprs.org/ip_ipm/IOBC_Pesticide_Side_Effect_ Database.html), websites of producers of beneficial organisms or via app's provided by producers of beneficial organisms on a smart phone.

\subsection{Making Implementation of IPM a Success}

In this chapter we will not discuss implementation of IPM in detail, this topic will be treated in Chap. 16. From behind a desk it is rather easy to develop a set of guidelines for implementation of IPM. Each practical situation dictates, however, a number of special aspects for consideration, which we will present below. We have experienced during the past decades that implementation of IPM in greenhouses in some crops and regions (e.g. vegetables in temperate climates) is much easier than in others (e.g. vegetables in semi-tropical climates, and ornamentals in all climates) because of differences in attitudes of growers, in climate, in greenhouse design, in culture methods and in composition of the pest complex. When considering to start working on an IPM project from scratch it is important to formulate targets for research. In Table 6.2, the targets for research are formulated for new and already running IPM programmes. 
Table 6.2 Targets for IPM research

\section{A. Targets for research if IPM is not yet in use}

Verify if biological control and other non-chemical methods have a chance of implementation (attitudes of growers and policy makers, possibilities for production of natural enemies, availability of other non-chemical control methods, etc.)

Make an inventory of pest, disease and weeds problems the specific crop

Check whether supposed status (importance) of the pests is estimated correctly, exaggerated or underestimated, and estimate economic threshold densities

Find out (through literature search and correspondence) which of the pests can be controlled by existing non-chemical control methods, exploring the entire spectrum from cultural methods, host-plant resistance and mechanical control to biological control, based on the overview of Table 6.1

Determine which pests can be controlled only with regular applications of broad spectrum pesticides. If these are key pests, their control will interfere with the use of biocontrol and IPM. A solution for the management of these pests must be found before introduction of biocontrol agents will be possible. If no short-term non-chemical solution for management of such key pests can be found, these pests will become priority targets for biological control research

If biological control methods or other non-chemical or selective chemical control methods are available for all pests and diseases, an IPM programme can be designed and tested under semi-commercial conditions. An extension programme will have to be implemented and a reliable delivery programme for control agents should be developed

\section{B. Targets for research in ongoing IPM programmes}

Identify potential pests which might be introduced into protected crops from elsewhere and become invasive. Make an inventory of available control strategies which are compatible with the ongoing IPM programme. Such studies of anticipated invasive pests can prevent panic actions which disrupt biological control of the previously established pests

If key pests are all under non-chemical control, start to evaluate natural enemies or other selective control methods for secondary pests

Start to develop biocontrol for pests which are presently controlled by selective pesticides that will be removed from the market

Further develop the toolbox of biocontrol solutions against diseases, especially those still poorly covered by currently available products, both in major and in minor crops

Increase the resilience of the total IPM system, e.g. by using polyphagous natural enemies, by preventative release or inoculation methods, and by increasing the diversity of tools available in the IPM toolbox

Successful IPM programmes for greenhouse crops have a number of characteristics in common. First of all, their use was promoted only after a complete IPM programme had been developed, covering all aspects of pest control for a crop. Secondly, an intensive support of the IPM programme by the advisory/extension service or by the provider of biological control agents was necessary during the first years. Next, the total costs of crop protection in the IPM programme were not higher than in the chemical control programme, or, if the management methods of IPM were more expensive, these costs should be more than compensated by a higher yield, a higher price for the produce, and better produce quality. Finally, nonchemical management methods (like biological control agents and resistant plant material) had to be as easily available, as reliable, as constant in quality and their deployment had to be as well guided as for chemical agents (van Lenteren 1993). 
Below we describe how success was obtained in northern Europe by forming voluntary working groups of researchers, extension agents and growers. Similar results have elsewhere been obtained by study groups formed by growers.

An implication in IPM research and implementation in greenhouses for several decades has taught a number of essential lessons on ways to obtain success, which were earlier presented in van Lenteren (2009). One of these lesson is that the development of an IPM programme needs to be discussed in a very early stage with all stakeholders, including growers, pest control specialists (all kinds of control methods), extension service and researchers (e.g. plant breeders, entomologists, phytopathologists etc.). The initiative for a start-up meeting can be from any group of stakeholders. It could result, for example, from an interest in applying IPM in a new setting or to adapt an existing programme threatened by the recent emergence of a new pest. The conclusion of such a meeting might be that IPM is the best solution or not. A major point is always that a complete pest management programme should be available, covering all aspects of pest management. If, for example, one of the chemical pesticides used for arthropod, disease or weed control is having a strong negative side effect on a new natural enemy, biological control is not realistic until an alternative for this pesticide has been found. What follows from these initial meetings is a pragmatic design of a draft IPM programme, for example for the management of the new emerging pest mentioned above, including an overall IPM programme for the other pests and diseases. This is then discussed in follow-up meetings with the stakeholders until agreement has been reached about the applicability of the programme. Next, the IPM programme is continuously adapted during later meetings, based on growers experience and new research results. Often, the development of these IPM programmes was made possible thanks to intensive cooperation within, and provision of essential information by, the European and North American Working Groups of the International Organization for Biological Control (see www.IOBC-WPRS.org for working group details and publications).

Also, it is crucial to cooperate with the most progressive growers. To our initial surprise, they were keenly interested, took up the knowledge quickly, suggested many improvements concerning release of biological control agents and sampling methods for pests, saw possibilities to advertise crops produced under IPM, and they were able to convince other less progressive growers how useful IPM was. It was these growers who allowed us to do experiments in their commercial greenhouses, and who invited other growers and the extension service to demonstrate how well biological control and IPM worked. We could not have found better advocates for implementation of IPM!

Often at the start of introducing IPM, growers had a wrong perception of IPM or had even never heard about it. It was necessary to develop teaching material for vocational schools, high schools and universities. Teachers of science and biology were often happy that they could link the development of an applied ecological method that was beneficial for the environment to general biological issues. The result was that teaching of biological control and IPM took off quickly and had a clear impact on changes in thinking about crop protection: children and students taught their parents how biological control worked within an IPM approach. 
We also realized that it was necessary to retrain the personnel of the extension service. Next, and often together with the extension service, we organized free courses on IPM and biological control to train the farmers in recognizing the natural enemies and pests, and in sampling and release methods. In addition to training, we started to publish about IPM in journals that the growers use primarily for obtaining the newest information on production and crop protection techniques.

During initial periods of implementation of IPM we were confronted with the fact that many small companies sold IPM products, including biological control agents, of poor quality and without providing sufficient guidance. The danger of selling IPM materials without guidance is that if they do not work, the grower is disappointed and will speak negatively of IPM. Therefore, producers of biocontrol agents and IPM materials should preferably provide a guidance information system that is sold to the growers for a certain price, including provision of the biocontrol agents and other crop protection materials. For control of insects and mites, this is now an accepted way of work, but it seems to be more difficult for disease control.

Biocontrol researchers should realize that pushing for biological control as the only solution to control pests might not always be realistic, because sometimes biocontrol is not the best solution. An example is pest control in short-term crops, like lettuce, which is produced during 6-week cycles. One of the main pests is aphids, a notoriously quick developing pest which is difficult to control in all greenhouse crops. In the 1980s we were able to keep aphids under biological control with frequent releases of great numbers of a whole array of natural enemies in lettuce, but it was too expensive and complicated to apply to be of practical use. At that time, we had to conclude that development of host-plant resistance to aphids was a better approach for developing IPM in lettuce, and when this was realized and became a success, we could advise to apply biocontrol for other pests, like leafminers (de Ponti and Mollema 1992). Recently, the situation has changed and lacewing (Chrysoperla carnea, see Chap. 20) are increasingly used for aphid control in lettuce, for example in France (Chambre d'Agriculture des Bouches-du-Rhône 2017).

And finally, it may be most important to try to get IPM accepted as an official plant protection philosophy at national and international level. This happened for example in Indonesia for a specific crop, rice (Röling and van de Fliert 1994). In other cases it included all crops, like in The Netherlands (Dutch Ministry of Agriculture 2005) or in France with the National Action Plan "Ecophyto" (Cerf et al. 2017). Currently, at an international level, the European Union is strongly supporting implementation of IPM both by providing grants to develop IPM programmes, as well as by supporting policies that lead to a quicker registration of alternative pest control methods needed in IPM programmes (EC 2009). The establishment of farmers groups is also a very powerful tool to foster progress in IPM development and adoption, as experienced for example in the "DEPHY Ferme" network of 1900 growers recently set up in France in the framework of the "Ecophyto" National Action Plan (http://www.chambres-agriculture.fr/ rechercheinnovation/dephy-ecophyto/). 


\subsection{Concluding Remarks}

IPM in greenhouses is currently well developed and applied in many countries worldwide. IPM in protected cultivation was initially limited mainly to the control of arthropods (van Lenteren and Woets 1988) and the majority of arthropods can now be controlled with biological control agents. In parallel with the development of biological control for arthropod pests, diseases were basically controlled with crop plant resistance and it was likely the main reason of the slower development of biological control of plant pathogens. Plant pathogens are creating frequent problems in greenhouses, but only some fungicides can be integrated with the use natural enemies (www.iobc-wprs.org/ip_ipm/IOBC_Pesticide_Side_Effect_Database. html). As problems of fungicide resistance are strongly increasing, fewer "relatively safe" fungicides remain available. Thus, serious negative effects of fungicides on natural enemies of insects and widespread resistance of foliar pathogens to fungicides demands for alternatives. As a result, disease management is now evolving towards strategies relying on the use of resistant cultivars and manipulation of the environment, in particular relative humidity. During the past decades several initiatives have led to research in non-chemical control, such as the effect of soil solarization on nematodes and fungi, and the potential use of antagonistic leaf fungi (Albajes et al. 1999). For an overview of recent successes and practical applications with disease suppressive soils, biological control of soil-borne pathogens and root, stem or foliar diseases, we refer to Chaps. 12 and 13. Several microbial products now are registered and used for disease control in greenhouse vegetables and ornamentals Europe, and other bacterial and fungal products for control of fungi are in the last phase of the registration procedure.

IPM programmes are more complicated than pure chemical control, ask continuous attention and need to be adapted regularly, depending on changes in the production system, the crop cultivars used and emergence of new pests. However, the greater demands for IPM solutions from researchers and growers will result in a cleaner environment, a richer biodiversity and a better health.

\section{References}

Achuo EA, Prinsen E, Hofte M (2006) Influence of drought, salt stress and abscisic acid on the resistance of tomato to Botrytis cinerea and Oidium neolycopersici. Plant Pathol 55(2):178186. https://doi.org/10.1111/j.1365-3059.2006.01340.x

Albajes R, Gullino ML, van Lenteren JC, Elad Y (eds) (1999) Integrated pest and disease management in Greenhouse crops. Kluwer Publishers, Dordrecht. 545 pp

Albert R, Kunstler A, Lantos F, Adam AL, Kiraly L (2017) Graft-transmissible resistance of cherry pepper (Capsicum апnиит var. cerasiforme) to powdery mildew (Leveillula taurica) is associated with elevated superoxide accumulation, NADPH oxidase activity and pathogenesisrelated gene expression. Acta Physiologiae Plantarum 39(2) doi:https://doi.org/10.1007/ s11738-017-2353-5 
Bacon SJ, Bacher S, Aebi A (2012) Gaps in border controls are related to quarantine alien insect invasions in Europe. PLoS One 7(10):e47689

Benuzzi M, Ladurner E (2017) Plant protection tools in organic farming. In: Vacante V, Kreiter S (eds) Handbook of pest management in organic farming. CABI, Wallingford, pp 24-59

Bourguet D, Guillemaud T (2016) The hidden and external costs of pesticide use. In: Lightfouse E (ed) Sustanable agriculture reviews. Springer, Dordrecht, pp 35-120

Butler DM, Kokalis-Burelle N, Albano JP, McCollum TG, Muramoto J, Shennan C, Rosskopf EN (2014) Anaerobic soil disinfestation (ASD) combined with soil solarization as a methyl bromide alternative: vegetable crop performance and soil nutrient dynamics. Plant Soil 378(1):365-381. https://doi.org/10.1007/s11104-014-2030-z

Buurma JS, Lamine C, Haynes I (2012) Transition to consumer-driven value chains in The Netherlands. Acta Hortic 2012:69-76

Calvo FJ, Bolckmans K, Belda JE (2012a) Release rate for a pre-plant application of Nesidiocoris tenuis for Bemisia tabaci control in tomato. BioControl 57:809-817

Calvo FJ, Bolckmans K, Belda JE (2012b) Biological control-based IPM in sweet pepper greenhouses using Amblyseius swirskii (Acari: Phytoseiidae). Biocontrol Sci Tech 22:1398-1416

CBD (1993) Convention on biological diversity (with annexes). Concluded at Rio de Janeiro on 5 June 1992. United Nation Treaty Ser 1760(30619):142-382

Cerf M, Bail L, Lusson M, Omon B (2017) Contrasting intermediation practices in various advisory service networks in the case of the French Ecophyto plan. J Agric Educ Ext 23(3):231244. https://doi.org/10.1080/1389224x.2017.1320641

Chambre d'Agriculture des Bouches-du-Rhône (2017) Salades d'abri en Provence Se protéger des pucerons. http://www.grab.fr/wp-content/uploads/2017/10/6-fiche-APREL-CA-13-chrysopecontre-pucerons-salade-2017.pdf. Accessed on 22 Dec 2017

Cock MJW, van Lenteren JC, Brodeur J, Barratt BIP, Bigler F, Bolckmans K, Consoli FL, Haas F, Mason PG, Parra JRP (2010) Do new access and benefit sharing procedures under the convention on biological diversity threaten the future of biological control? BioControl 55:199-218

Colla G, Rouphael Y (2015) Biostimulants in horticulture. Sci Hortic 196(Supplement C):1-2. https://doi.org/10.1016/j.scienta.2015.10.044

Datnoff LE, Elmer WH, Huber DM (2007) Mineral nutrition and plant disease. American Phytopathological Society (APS Press), St. Paul

de Ponti OMB, Mollema C (1992) Emerging breeding strategies for insect resistance. In: Stalker HT, Murphy JP (eds) Plant breeding in the 1990s. CABI Publishing, Wallingford, pp 323-347

Decognet V, Ravetti F, Martin C, Nicot PC (2010) Improved leaf pruning reduces development of stem cankers caused by grey mould in greenhouse tomatoes. Agron Sustain Dev 30(2):465-472

Dicke M (2016) Plant phenotypic plasticity in the phytobiome: a volatile issue. Curr Opin Plant Biol 32:17-23

Dutch Ministry of Agriculture (2005) Durable crop protection: policy for crop protection towards 2010. Dutch Ministry of Agriculture, Nature and Food Quality, Den Haag

EC (2009) Sustainable use directive. European Parliament and of the council of 21 October 2009 establishing a framework for community action to achieve the sustainable use of pesticides. Off J Eur Union L309:71-86

Erisman JW, van Eekeren N, de Wit J, Koopmans C, Cuijpers W, Oerlemans N, Koks BJ (2016) Agriculture and biodiversity: a better balance benefits both. AIMS Agric Food 1:157-174

FAO/IPPC (1997) International plant protection convention. FAO, Rome

Fenoll J, Garrido I, Vela N, Ros C, Navarro S (2017) Enhanced degradation of spiro-insecticides and their leacher enol derivatives in soil by solarization and biosolarization techniques. Environ Sci Pollut Res 24(10):9278-9285. https://doi.org/10.1007/s11356-017-8589-1

Gamliel A, van Bruggen AHC (2016) Maintaining soil health for crop production in organic greenhouses. Sci Hortic 208(Supplement C):120-130. https://doi.org/10.1016/j.scienta.2015.12.030

Grumet R, Colle M, Ando K, Xie D-S, Havenga L, Switzenberg JA (2013) Modified plant architecture to enhance crop disease control: genetic control and possible value of upright fruit position in cucumber. Eur J Plant Pathol 135(3):545-560. https://doi.org/10.1007/s10658-012-0087-1 
Han P, Lavoir AV, Le Bot J, Amiens-Desneux E, Desneux N (2014) Nitrogen and water availability to tomato plants triggers bottom-up effects on the leafminer Tuta absoluta. Sci Rep 4:8. https:// doi.org/10.1038/srep04455

Hoffland E, Jeger MJ, van Beusichem ML (2000) Effect of nitrogen supply rate on disease resistance in tomato depends on the pathogen. Plant Soil 218(1-2):239-247. https://doi.org/10.10 23/a:1014960507981

Jørgensen LN, Bosch F, Oliver RP, Heick TM, Paveley ND (2017) Targeting fungicide inputs according to need. Annu Rev Phytopathol 55(1):181-203. https://doi.org/10.1146/ annurev-phyto-080516-035357

Kappers IF, Hoogerbrugge H, Bouwmeester HJ, Dicke M (2011) Variation in herbivory-induced volatiles among cucumber (Cucumis sativus $\mathrm{L}$.) varieties has consequences for the attraction of carnivorous natural enemies. J Chem Ecol 37:150-160

Katan J (2017) Disease caused by soilborne pathogens: biology, management and challenges. J Plant Pathol 99(2):305-315

Kyriacou MC, Rouphael Y, Colla G, Zrenner R, Schwarz D (2017) Vegetable grafting: the implications of a growing agronomic imperative for vegetable fruit quality and nutritive value. Front Plant Sci 8:741. https://doi.org/10.3389/fpls.2017.00741

La Torre A, Battaglia V, Caradonia F (2016) An overview of the current plant biostimulant legislations in different European member states. J Sci Food Agric 96(3):727-734. https://doi. org $/ 10.1002 /$ jsfa. 7358

Le Mire G, Nguyen ML, Fassotte B, du Jardin P, Verheggen F, Delaplace P, Jijakli MH (2016) Implementing plant biostimulants and biocontrol strategies in the agroecological management of cultivated ecosystems. A review. Biotechnol Agron Soc 20:299-313

Louws FJ, Rivard CL, Kubota C (2010) Grafting fruiting vegetables to manage soilborne pathogens, foliar pathogens, arthropods and weeds. Sci Hortic 127(2):127-146. https://doi. org/10.1016/j.scienta.2010.09.023

Mason PG, Cock MJW, Barratt BIP, van Lenteren JC, Brodeur J, Klapwijk JN, Consôli FL, Hoelmer K, Heimpel GE (2018) Best practices for the use and exchange of biological control genetic resources relevant for food and agriculture. BioControl. https://doi.org/10.1007/ s10526-017-9810-3

Mazzola M, Freilich S (2017) Prospects for biological soilborne disease control: application of indigenous versus synthetic microbiomes. Phytopathology 107(3):256-263. https://doi. org/10.1094/phyto-09-16-0330-rvw

Messelink GJ, Bennison J, Alomar O, Ingegno BL, Tavella L, Shipp L, Palevsky E, Wäckers FL (2014) Approaches to conserving natural enemy populations in greenhouse crops: current methods and future prospects. BioControl 59:377-393

Nicot PC, Bardin M (2012) Biological and integrated protection in the Mediterranean greenhouse: is disease management the weak link? IOBC WPRS Bull 80:11-17

Nicot PC, Fabre R, Lebkara T, Ozayou S, Abro MA, Duffaud M, Lecompte F, Jeannequin B (2012) Manipulating nitrogen fertilization for the management of diseases in the tomato greenhouse: what perspectives for IPM? IOBC WPRS Bull 80:333-338

Norldlund DA, Jones RL, Lewis WJ (1981) Semiochemicals and their role in pest control. Wiley, New York

Oka Y, Shapira N, Fine P (2007) Control of root-knot nematodes in organic farming systems by organic amendments and soil solarization. Crop Prot 26(10):1556-1565. https://doi. org/10.1016/j.cropro.2007.01.003

Öz H, Coskan A, Atilgan A (2017) Determination of effects of various plastic covers and biofumigation on soil temperature and soil nitrogen form in greenhouse solarization: new solarization cover material. J Polym Environ 25(2):370-377. https://doi.org/10.1007/s10924-016-0819-y

Pane C, Villecco D, Pentangelo A, Lahoz E, Zaccardelli M (2012) Integration of soil solarization with Brassica carinata seed meals amendment in a greenhouse lettuce production system. Acta Agric Scand B Soil Plant Sci 62(4):291-299. https://doi.org/10.1080/09064710.2011.613850 
Pannacci E, Lattanzi B, Tei F (2017) Non-chemical weed management strategies in minor crops: a review. Crop Prot 96(Supplement C):44-58. https://doi.org/10.1016/j.cropro.2017.01.012

Pappas ML, Broekgaarden C, Broufas GD, Kant MR, Messelink GJ, Steppuhn A, Wackers F, van Dam NM (2017) Induced plant defences in biological control of arthropod pests: a doubleedged sword. Pest Manag Sci 73(9):1780-1788. https://doi.org/10.1002/ps.4587

Pérez-Hedo M, Suay R, Alonso M, Ruocco M, Giorgini M, Poncet C, Urbaneja A (2017) Resilience and robustness of IPM in protected horticulture in the face of potential invasive pests. Crop Prot 97:119-127

Pimentel D, Burgess M (2014) Environmental and economic costs of the application of pesticides primarily in the United States. In: Pimentel D, Peshin R (eds) Integrated pest management. Springer, Dordrecht, pp 47-71

Prenafeta-Boldu FX, Trillas I, Vinas M, Guivernau M, Caceres R, Marfa O (2017) Effectiveness of a full-scale horizontal slow sand filter for controlling phytopathogens in recirculating hydroponics: from microbial isolation to full microbiome assessment. Sci Total Environ 599:780 788. https://doi.org/10.1016/j.scitotenv.2017.04.221

Radcliffe EB, Hutchinson WD, Cancelado RE (eds) (2009) Integrated pest management: concepts, tactics, strategies and case studies. Cambridge University Press, Cambridge

Röling NG, van de Fliert E (1994) Transforming extension for sustainable agriculture: the case of integrated pest management in rice in Indonesia. Agric Hum Values 11:96-108

Scarlett K, Collins D, Tesoriero L, Jewell L, van Ogtrop F, Daniel R (2016) Efficacy of chlorine, chlorine dioxide and ultraviolet radiation as disinfectants against plant pathogens in irrigation water. Eur J Plant Pathol 145(1):27-38. https://doi.org/10.1007/s10658-015-0811-8

Schlatter D, Kinkel L, Thomashow L, Weller D, Paulitz T (2017) Disease suppressive soils: new insights from the soil microbiome. Phytopathology 107(11):1284-1297. https://doi. org/10.1094/phyto-03-17-0111-rvw

Schwarz D, Rouphael Y, Colla G, Venema JH (2010) Grafting as a tool to improve tolerance of vegetables to abiotic stresses: thermal stress, water stress and organic pollutants. Sci Hortic 127(2):162-171. https://doi.org/10.1016/j.scienta.2010.09.016

Seebens H, Blackburn TM, Dyer EE, Genovesi P, Hulme PE, Jeschke JM, Pagad S, Pysek P, Winter M, Arianoutsou M, Bacher S, Blasius B, Brundu G, Capinha C, Celesti-Grapov L, Dawson W, Dullinger S, Fuentes N, Jaeger H, Kartesz J, Kenis M, Kreft H, Kuehn L, Lenzner B, Liebhold A, Mosena A, Moser D, Nishino M, Pearman D, Pergl J, Rabitsch W, RojasSandoval J, Roques A, Rorke S, Rossinelli S, Roy HE, Scalera R, Schindler S, Stajerova K, Tokarska-Guzik B, van Kleunen M, Walker K, Weigelt P, Yamanaka T, Essl F (2017) No saturation in the accumulation of alien species worldwide. Nat Commun 8(14435):1-9. https://doi. org/10.1038/ncomms 14435

Shrestha U, Auge RM, Butler DM (2016) A meta-analysis of the impact of anaerobic soil disinfestation on pest suppression and yield of horticultural crops. Front Plant Sci 7:20. https://doi. org/10.3389/fpls.2016.01254

Suthaparan A, Solhaug KA, Stensvand A, Gislerod HR (2017) Daily light integral and day light quality: potentials and pitfalls of nighttime UV treatments on cucumber powdery mildew. J Photochem Photobiol B Biol 175:141-148. https://doi.org/10.1016/j.jphotobiol.2017.08.041

Tillman D, Reich P, Isbell F (2012) Biodiversity impacts ecosystem productivity as much as resources, disturbance or herbivory. PNAS 109:10394-10397

Tivoli B, Calonnec A, Richard B, Ney B, Andrivon D (2013) Current knowledge on plant/canopy architectural traits that reduce the expression and development of epidemics. Eur J Plant Pathol 135(3):471-478. https://doi.org/10.1007/s10658-012-0066-6

van Lenteren JC (1993) Integrated pest management: the inescapable future. In: Zadoks JC (ed) Modern crop protection: developments and perspectives. Wageningen Pers, Wageningen, pp 217-225

van Lenteren JC (2000) A greenhouse without pesticides: fact or fantasy? Crop Prot 19(6):375384. https://doi.org/10.1016/S0261-2194(00)00038-7 
van Lenteren JC (2009) In: Radcliffe EB, Hutchinson WD, Cancelado RE (eds) IPM in greenhouse vegetables and ornamentals. Integrated Pest management: concepts, tactics, strategies and case studies. Cambridge University Press, Cambridge, pp 354-365

van Lenteren JC, Woets J (1988) Biological and integrated pest control in greenhouses. Annu Rev Entomol 33:239-269. https://doi.org/10.1146/annurev.en.33.010188.001323

van Lenteren JC, Bolckmans K, Köhl J, Ravensberg W, Urbaneja A (2018) Biological control using invertebrates and microorganisms: plenty of new opportunities. BioControl. https://doi. org/10.1007/s10526-017-9801-4

Vargas-Hernandez M, Macias-Bobadilla I, Guevara-Gonzalez RG, Romero-Gomez SD, RicoGarcia E, Ocampo-Velazquez RV, Alvarez-Arquieta LD, Torres-Pacheco I (2017) Plant Hormesis management with biostimulants of biotic origin in agriculture. Front Plant Sci 8:11. https://doi.org/10.3389/fpls.2017.01762

Vela N, Fenoll J, Navarro G, Garrido I, Navarro S (2017) Trial of solar heating methods (solarization and biosolarization) to reduce persistence of neonicotinoid and diamide insecticides in a semiarid Mediterranean soil. Sci Total Environ. 590-591 (Supplement C):325-332. https://doi. org/10.1016/j.scitotenv.2017.03.013

Ximenez-Embun MG, Castanera P, Ortego F (2017) Drought stress in tomato increases the performance of adapted and non-adapted strains of Tetranychus urticae. J Insect Physiol 96:73-81. https://doi.org/10.1016/j.jinsphys.2016.10.015

$\mathrm{Xu}$ XM, Robinson J, Else MA (2013) Effects of nitrogen input and deficit irrigation within the commercial acceptable range on susceptibility of strawberry leaves to powdery mildew. Eur $\mathbf{J}$ Plant Pathol 135(4):695-701. https://doi.org/10.1007/s10658-012-0106-2

Yakhin OI, Lubyanov AA, Yakhin IA, Brown PH (2017) Biostimulants in plant science: a global perspective. Front Plant Sci 7:32. https://doi.org/10.3389/fpls.2016.02049 